1986

\title{
Reconstructing the Criminal Defenses: The Significance of Justification
}

Thomas Morawetz

University of Connecticut School of Law

Follow this and additional works at: https://opencommons.uconn.edu/law_papers

Part of the Criminal Law Commons, and the Law and Philosophy Commons

\section{Recommended Citation}

Morawetz, Thomas, "Reconstructing the Criminal Defenses: The Significance of Justification" (1986). Faculty Articles and Papers. 315. https://opencommons.uconn.edu/law_papers/315 


\section{HEINONLINE}

Citation: 77 J. Crim. L. \& Criminology 2771986

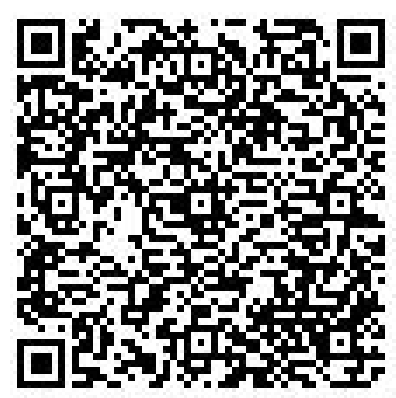

Content downloaded/printed from

HeinOnline (http://heinonline.org)

Mon Aug 15 17:11:55 2016

-- Your use of this HeinOnline PDF indicates your acceptance of HeinOnline's Terms and Conditions of the license agreement available at http://heinonline.org/HOL/License

-- The search text of this PDF is generated from uncorrected OCR text.

-- To obtain permission to use this article beyond the scope of your HeinOnline license, please use:

https://www.copyright.com/ccc/basicSearch.do?

\&operation $=$ go\&search Type $=0$

\&lastSearch=simple\&all=on\&titleOrStdNo=0091-4169 


\title{
CRIMINAL LAW
}

\section{RECONSTRUCTING THE CRIMINAL DEFENSES: THE SIGNIFICANCE OF JUSTIFICATION}

\author{
Thomas Morawetz*
}

The intersection between morality and law is nowhere more evident than in the criminal defenses. The general notion underlying the criminal defenses is captured by the claim, "Yes, I have committed harm but there are decisive reasons why I should not be held to blame or punished for my action."1 The harm involved is the kind of harm anticipated by the criminal law (taking life, doing injury,

* Professor of Law, University of Connecticut School of Law. J.D., Yale Law School, 1968; Ph.D., Yale University, 1969; M. Phil., Yale University, 1968; A.B., Harvard College, 1963. This paper was written while Professor Morawetz was a fellow at the Woodrow Wilson International Center for Scholars, Smithsonian Institution. Professor Morawetz wishes to thank the Center for its support and the members of the Center for Philosophy and Public Policy at the University of Maryland for their helpful suggestions.

1 In his comprehensive and illuminating survey of criminal defenses, Paul Robinson sets out five categories of criminal law defenses which he defines as "any set of identifiable conditions or circumstances which may prevent a conviction for an offense." Robinson, Criminal Law Defenses: A Systematic Analysis, 82 Colum. L. Rev. 199, 203 (1982)[hereinafter Robinson]. See also P. Robinson, Criminal Law Defenses (1984)[hereinafter Criminal Law Defenses]. The five catagories are: failure of proof defenses, offense modification defenses, justifications, excuses, and nonexculpatory public policy defenses (such as the statute of limitations). Robinson, supra at 203. In line with most discussions of criminal law defenses, I am concerned here only with the third and fourth categories: justifications and excuses. These involve situations in which the elements of the offense are satisfied and the actor claims that there are sufficient grounds for personal exculpation, moral as well as legal. The first two categories on the other hand involve situations in which the elements of the offense are, for various reasons, not established. The last category involves situations in which the grounds of nonprosecution do not amount to moral exculpation. These distinctions notwithstanding, Robinson's caveats concerning overlaps and intersections among these categories should be kept in mind. Robinson, supra, at 232-43.

In limiting my discussion to justifications and excuses, I concern myself with problems and suggestions raised by George Fletcher and Kent Greenawalt in articles prepared for a workshop on comparative German and Anglo-American criminal law held in Freiberg, West Germany, July, 1984. See Fletcher, The Right and the Reasonable, 98 
depriving one of property) and the defensive reasons are ones recognized by law. At the same time criminal defenses represent moral judgments. Each category of criminal defense mirrors and amplifies what is arguably a criterion for moral blamelessness ${ }^{2}$ and every species of moral exculpation seems to demand legal recognition. ${ }^{3}$

The familiar categories of defenses ${ }^{4}$ - self defense, duress, necessity, mistake, privilege, ${ }^{5}$ intoxication-are heterogeneous. The situations and sources of human action are varied and complex and there is no a priori reason to think that the bases of moral exculpation sort themselves into simple categories. At the same time, not just the law, but also human understanding, demands categorization, however Procrustean the result. The criminal defenses, with relatively little deformation, seem to sort themselves out into two groups, justifications and excuses. Privilege and self-defense are examples of justifications. The policeman, empowered to place sus-

HaRv. L. Rev. 949 (1985) and Greenawalt, The Perplexing Borders of Justification and Excuse, 84 Colum. L. Rev. 1897 (1984).

2 Some criminal defenses exculpate only in part and are thus the grounds for a finding of diminished responsibility. In accord with the relevant statutes in a particular jurisdiction, negligent conduct or extreme emotional distress may justify a diminution of the charges from murder to manslaughter or manslaughter to negligent homicide (in the case of homicide), from aggravated assault to simple assault, etc. See W. LaFAve \& A. Scott, Substantive Criminal Law $\S 3.7$ (1986). Intoxication will often mitigate rather than exculpate. See id. at $\$ 4.10$.

To simplify, if the discussion I address mainly exculpating rather than mitigating defenses. In doing so I follow Fletcher, supra note I, and Greenawalt, supra note 1.

3 This conclusion needs to be qualified in at least two ways. First, in some cases that do not fall under any standard legal defenses, the actor may be morally blameless because her motives are "pure" or admirable. Acts of civil disobedience are punishable notwithstanding the fact that the general public and indeed the judge may admire and sympathize with the actor's motives. The law distinguishes between motive and intent; intent to do harm is usually required as an element of the offense and the moral praiseworthiness of the purpose or motive is ordinarily irrelevant to the question of guilt or innocence. See W. LaFave \& A. Scott, Criminal Law $\$ 3.6$ (2d ed. 1986).

Secondly, an exception to the statement in the text is represented by strict liability offenses. In certain instances the legal response is determined by a public policy imposing a special duty of care upon actors, forcing them to assume the risk of liability if any harm results from their action. In such cases, legal liability may exist even when the actor is morally blameless. For an exhaustive discussion of the theory of strict liability, see G. Fletcher, Rethinking Criminal Law 713-36 (1978).

4 The general theory of criminal defenses is discussed infra text accompanying notes 22-35.

5 I shall use the term "privilege" to refer to those justifications, sometimes called "authority," which Robinson describes as follows:

The use of public authority justification is often limited to certain persons whose position or training makes them particularly appropriate protectors of the interest at stake. These interests may be personal or societal; they include law enforcement, child-rearing and education, safety and order on public transportation vehicles or in institutions, life or health ..., judicial, military, and other public authority generally.

Robinson, supra note 1 , at 216. 
pects under arrest, may use minimal force and thus inflict harm but he does not thereby commit an assault. Rather, he is justified in using minimal force. Analogously, one may use force sufficient to ward off an (impermissible) ${ }^{6}$ assault even if the resulting harm is fatal to the attacker.

In his extensive writings on criminal law generally and the criminal defenses in particular, George Fletcher finds it useful to identify a distinctive feature of justifications as allowing us to distinguish cases of causing harm from cases of doing wrong. ${ }^{7}$ Justified cases of harming are not wrong and do not stir feelings of blame and retribution; rather, they are socially approved. Social approval, in turn, may be explained by the appeal to shared social interests or shared moral beliefs. 8

Excused behavior, on the other hand, is not approved. A harmful drunken assault is wrong and morally blameworthy. In allowing involuntary intoxication as a defense, the law does not part company with morality, but rather recognizes a distinction in seriousness and blameworthiness. Deliberate assaults by those who have their wits about them and carry out harmful intentions are more blameworthy than assaults by those who have lost control. Criminal law exists to punish the more serious lapses. ${ }^{9}$

George Fletcher and Paul Robinson ${ }^{10}$ have both commended the conceptual clarity that comes from distinguishing sharply between justifications and excuses. Fletcher makes three claims in support of this distinction. First, criminal defenses can usefully be

6 An assault is not an offense if, for example, one has the explicit or implicit consent of the victim. Criminal LAW, supra note 3, at \$ 5.11. In other words, for legal purposes, an assault is an unconsented touching.

7 The relationship of wrongdoing and harm is discussed at great length and with much subtlety by Fletcher in Rethinking Criminal Law. G. Fletcher, supra note 3, at 454-91, 515-79 (particularly 472-83). The theory that I attribute to Fletcher in this article is a simplified one and is to be gleaned from The Right and the Reasonable. See Fletcher, supra note 1. I have not attempted to discuss the relationship between the fuller discussion in Fletcher's book and the briefer discussion in his article. See infra text accompanying notes $45-61$.

8 I discuss infra part II whether or not a utilitarian account of justifications provides the best understanding of their moral foundations. Fletcher seems to reject a utilitarian account for a retributive one, while Robinson seems sympathetic to utilitarianism. Compare Fletcher, supra note 1, at 957-61 with Robinson, supra note 1, at 216-20.

9 This is not to deny, of course, that criminal law sometimes punishes minor lapses under the rubric of misdemeanors. The point rather is that one who is convicted of a serious offense must be said to have had some opportunity to comply with the law and to have foregone that opportunity either through extreme recklessness or malign intent. See infra text accompanying note 48.

10 See supra note 1. See especially, Criminal Law Defenses, supra note 1, at 100-01; Robinson, supra note 1, at 234-36, 241-43. 
sorted out into these two categories. Secondly, these categories illustrate and use an important distinction between two sorts of questions that criminal law must answer in every case of criminal liability: whether there has been wrongdoing and whether the wrong is to be attributed to a particular actor with the consequence of liability. ${ }^{11}$ The first question has, according to Fletcher, natural priority over the second. Unless a wrong has been done, there is not a wrong to attribute. ${ }^{12}$ Third, Fletcher's most abstract and perhaps most important claim is that such an ordering of questions, one that he finds in the German criminal code, demonstrates the virtues of structured legal thinking. This claim may take two forms. It may take the relatively modest form of stating that an ordered set of abstract questions and categories is indispensable for organizing and understanding a heterogenous body of empirical data, even when there are evident limitations and distortions in so doing. This form of the claim may be close to a truism, but it is also a reminder of what is implicit in investigation. The more ambitious form of the claim is that the categorical framework orders the data without distortion or ambiguity and indeed answers questions about the data that can be answered in no other way. ${ }^{13}$

Fletcher sometimes appears to defend structured thinking in this second way. ${ }^{14} \mathrm{He}$ seems to hold the view that the categories of

11 An exposition of structured thinking about criminal law in this form is the backbone of Rethinkinc Criminal Law. See G.Fletcher, supra note 3, at 454-514. A major theme of Fletcher's book is that

the German analysis of the distinction between wrongdoing and attribution goes far beyond the questions of insanity and infancy .... The primary focus of German theory in this century has been the attempt to elaborate a structure of liability for criminal acts by determining which issues are properly classified in one category or the other.

G. Fletcher, supra note 3, at 456 . Fletcher is in sympathy with this attempt and his assumption that the categories are hard-edged is one of the main topics critically examined infra.

12 This notion seems to have all the earmarks of a truism. But see infra text accompanying notes $94-95$.

13 There is more to this Procrustean problem than meets the eye. It is one thing to say that descriptive categories can be misleading because they involve unwarranted simplification or distortion. But legal categories are created with the purpose of simplifying the relevant data and making some factors relevant to the disposition of a problem and others irrelevant. The problem at hand is not, however, that of organizing chaotic and irrepressible nature into the categories of justification and excuse, but of observing how well and easily the various and familiar criminal defenses fit within the legal categories of justification and excuse.

14 Having identified structured thinking with the German legal culture and flat thinking (in terms of reasonableness) with the American legal culture, Fletcher repeatedly cites the clarificatory advantages of structured thinking.

The divergence of common law thinking from continental thinking on putative selfdefense derives from a matrix of inter-related assumptions. ... At the foundation 
justification and excuse are exhaustive and divide the defenses without residue or ambiguity. Secondly, he claims that difficult questions about borderline examples can be answered satisfactorily by an application of the structure. ${ }^{15}$ Kent Greenawalt has challenged this view by offering counterexamples to Fletcher's arguments and by questioning the usefulness of this application of structured thinking. Greenawalt argues that a fully systematic working out of the distinction between justifications and excuses is misguided in principle because the boundary between the concepts is inevitably unclear and because the distinction is undermined by "disagreements about substantive morality." 16

This article will reexamine the boundary between justifications and excuses in order to assess Fletcher's structure of analysis in particular and the role of structured thinking in this area in general. Part I sorts out criminal defenses into three, rather than two, categories: justified acts tout court, excused acts tout court, and "justified wrongs." One theme of Part $I$ is that the concept of a justified wrong is useful as a category of classification and is necessary to reconcile ordinary usage of the notion of justification with its legal usage. Part II applies this analysis to two closely related problems. It reviews some familiar difficulties of classifying and understanding the necessity defense and explains these difficulties by reference to uncertainty in the concept of wrongdoing.

Part III considers the relationship between justified wrongs and excused behavior in the context of trying to understand and classify the defense of duress. It concludes that our difficulties in understanding duress are reflections of deeper difficulties in understanding the psychology of control and responsibility. In this context the

of these assumptions lies the cement of reasonableness, a concept that enables Americans to blur distinctions between objective and subjective, self-defense and putative self-defense, justification and excuse.

Fletcher, supra note 1, at 979-80. Presumably blurring is not a good thing, especially since the several listed distinctions are said to be useful and to have hard edges. Yet Fletcher also protests that he is not being critical of "flat" thinking or thinking in which there is no "natural order" of questions: wrongdoing first and attribution second. See Fletcher, supra note 1, at 953.

15 Perceptive discussions that illustrate Fletcher's sensitivity to unresolved and unresolvable issues can be found in RETHINKING CRIMINAL LAw where he considers difficult applications of the defenses of necessity and duress. See G. FlETCHER, supra note 3, at 817-35, 855-64. Robinson's own diagnosis of problematic cases appears in Criminal Lazw Defenses. See Robinson, supra note 1, at 232-43.

16 See Greenawalt, supra note 1, at 1904-05. One of my arguments is that the difficulties inherent in understanding justifications and excuses have much less to do with moral disagreement than Greenawalt supposes and the kinds of disagreements he relies on are more or less irrelevant. In other words, the conceptual disagreements would persist even if there were perfect agreement on moral norms. 
defense of reasonable mistake ${ }^{17}$ is compared with duress for the purpose of seeing both defenses as plausible examples of different kinds of justified wrong. Part IV examines the familiar problems that flow from the rights and obligations of third parties in the face of justified and excused actions. Part $\mathrm{V}$ is about the implications of this analysis for the claim that justifications refer to general characteristics of the act and excuses refer to idiosyncratic characteristics of the actor. ${ }^{18}$ Finally, Part VI draws matters together with observations on the use and abuse of structured thinking in analyzing the criminal defenses.

\section{Justifications, Excuses, and Justified Wrongs}

It would be idle to discuss whether the distinction between justifications and excuses is moribund in Anglo-American law and legal scholarship. ${ }^{19}$ For many theorists, the distinction remains an important tool for pedagogy and investigation in the theory of criminal law. ${ }^{20}$ It is one thing, however, to attend to the distinction, and it is another to treat the distinction as hard-edged. Fletcher sees it as a tool for resolving uncertain examples and clarifying hard cases. Among other things, this article argues that it is unhelpful to see the current debate simply as one between those who view the distinction as a sharp one (Fletcher and Robinson) and those who view it as inevitably unclear (Greenawalt). ${ }^{21}$ The choice is not between a crystalline ordering and no ordering at all.

17 In referring to the defense of "reasonable mistake," I have in mind the MODEL PENAl CODE formulation of the defense according to which a reasonable mistake (of law or fact) exculpates if the act the actor thought he was carrying out, in the circumstances as he thought them to be, was a lawful act at the time of the action. For a discussion of the problematic distinction between mistakes of law and mistakes of fact, see MODEL PENAl Code, § 2.04 (1) (Proposed Official Draft 1962) and accompanying comments.

18 See, e.g., Robinson, supra note 1, at 229. "In determining whether conduct is justified, the focus is on the act, not the actor. An excuse represents a legal conclusion that the conduct is wrong, undesirable, but that criminal liability is inappropriate because some characteristic of the actor vitiates society's desire to punish him." Robinson, supra note I, at 229. See also Fletcher, supra note 1. "Claims of justification direct our attention to the propriety of the act in the abstract; claims of excuse, to the blameworthiness of the actor in the concrete situation." Fletcher, supra note 1, at 955 . We shall see in Part $\mathrm{V}$ that the act/actor distinction is substantially misleading.

19 See Fletcher, supra note 1, at 953-57.

20 See, e.g., W. LaFave \& A. ScotT, Handbook on Criminal Law 356-413 (1972). See also Eser, Justification and Excuse, 24 AM. J. CoMP. L. 621 (1976).

21 A distinction between two terms can be interestingly complex if each term has, for example, several overlapping criteria of use and the criteria for the two terms overlap. Identifying the criteria and illustrating the overlap can itself be a clarifying analysis. Vague references to "fuzzy" terms are simply a way of turning one's back on this job. See Greenawalt, supra note 1, at 6. For some methodological constraints, see L. Wittgenstein, Philosophical Investigations, Part I, § 1-34 (1953). 
Fletcher's ordering is simple, intuitively appealing, and may be assessed as follows. ${ }^{22}$ The basic distinction in this ordering is between two questions: Has the actor committed a wrong? Is the actor to be punished for his/her wrong action? Two conditions must be satisfied in a given situation before either of these questions is reached. First, the accused must in fact be the person who committed the acts in question, and second, the acts must have caused harm. The refined first question, is thus, Is the harmful act committed by this actor a wrong? The second question, in turn, must also be qualified. Even if the actor has committed a wrong, the second question may not be reached if the court does not have jurisdiction over the defendant, for example if he/she is an infant. The second question presupposes jurisdiction. ${ }^{23}$

The prima facie usefulness of the distinction between wrongdoing and attribution in explaining justification and excuses is clear. For example, justified acts, privileged acts of law enforcement or acts of self-defense, are harmful but not wrong. Any viable social policy would be likely to endorse the use of effective force by those employed to enforce the law and the right to defend oneself against imminent harm.

If it is clear that this result fits our moral intuitions, it is less clear what moral theory best explains the result. On the one hand, a utilitarian explanation seems satisfactory since it can be argued that society as a whole is best off, in the long and short-run, if law enforcement and self-defense are approved and encouraged. ${ }^{24}$ Utilita-

22 This ordering, as Fletcher correctly observes, is characteristic of the criminal codes of continental legal systems, but perhaps Fletcher underestimates the extent to which it also pervades common law. See Fletcher, supra note 1, at 954-57, 962-64. See also sources cited supra note 20. The MODEl PENAL CODE draws a similar sharp distinction between excuses and justifications, treating the former under "General Principles of Liability" and the latter under "General Principles of Justification." See Model Penal Code $\S \S 2$, 3.

23 As Robinson points out in explaining his fifth category of criminal law defenses, nonexculpatory public policy defenses, there are many ways in which a culpable defendant can escape the jurisdiction of the court. Having mentioned the statute of limitations and constitutional protection derived from the fourth, fifth and sixth amendments, Robinson refers to "diplomatic immunity, judicial, legislative, and executive immunities, immunity after compelled testimony or pursuant to a plea bargain or other agreement, and incompetency. ... Such nonexculpatory public policy concerns are at work whenever a dismissal is based on factors other than the innocence of the defendant." Robinson, supra note 1 , at 231 .

24 The nature and scope of utilitarian ethical theories have been matters of controversy for well over a hundred years. I am using the term in a way that has become generally favored among writers on ethical theory and that escapes some of the criticisms that classical formulations invited. Accordingly, an act or general practice is morally justified according to utilitarianism if it tends overall to benefit, rather than harm, those who are affected by it, if those affected by it are better off than they would be if the 
rianism also seems to account for the distinction between justifications and excuses. While justifications are just the sort of acts that contribute to well-being overall, excused acts do not contribute to well-being. The harmful acts of someone acting under a mental disability are not to be encouraged. There is no resulting benefit that outweighs the harm.

A utilitarian criterion for the defenses has limitations, however. Even if it yields a prima facie intelligible distinction between justification and excuses, it does not tell us why both justification and excuses are defenses but only why justifications are defenses. The utilitarian may respond that justifications and excuses are defenses for different reasons: justified acts contribute to well-being overall, while excuses should be defenses because harming the actor will neither undo the harm she has caused nor deter her from taking further harmful action since her original harmful act was not in her control. This response, however, is flawed. ${ }^{25}$ Punishing those who lack control may well contribute to well-being by (a) giving an incentive to those who can affect their actions to keep them out of trouble, (b) restraining and incapacitating them so that they are not in a position to cause harm and (c) giving persons in marginal situations, like duress, ${ }^{26}$ an additional reason to resist the pressure to act harmfully.

Utilitarianism is not only inadequate to explain excuses, but to explain justifications as well. A utilitarian endorsement of self-defense must presuppose that the harm done by a self-defender is less than the harm threatened to him. This assumption is unjustified when the response involves force approximately equal to the threatened force. The utilitarian may reply that justification does not depend on the results in the particular case, but on the results overall when self-defense is encouraged. This reply depends on the uncertain assumption that potential victims are less likely to get hurt, or are likely to get hurt less, if they resist than if they yield. Moreover, as the details of the utilitarian response are spelled out,

act or general practice did not occur. This account says nothing about the components and characteristics of benefit and harm, but rather assumes that there is some social consensus about these matters. For a discussion of utilitarianism, consequentialism, and "welfarism," see D. Lyons, The Forms and Limits of Utilitarianism (1965); H. Miller \& W. Williams, The Limits of Utilitarianism (1982); T. Morawetz, The PhiI.OSOPHy of LAW (1980); A. SEN \& B. Williams, Utilitarianism and Beyond (1982).

25 For a discussion of this point, see H. Hart, Punishment and Responsibiliti 19 (1968); Fletcher, Excuse: Theory, Encyclopedia of Crime and Justice 727 (1983).

26 Part III infra examines at some length the proper classification and understanding of duress. Robinson raises the question of whether it is an excuse or a justification in Robinson, supra note 1, at 240. 
they seem less and less relevant in principle. The right of self-defense seems to demand some vindication regardless of the consequences of self-defensive actions.

One suspects, therefore, that not only utilitarianism but some account of justice or retribution is implicated in the notion of wrongdoing that underlies the criminal defenses. ${ }^{27}$ On this view, certain kinds of purposeful action show disrespect for the integrity and rights of other persons and thus merit punishment, whatever the utilitarian consequences. Privileged acts and acts of self-defense do not fall into this category. The person who provokes harm loses his claim to respect or invulnerability to the extent that he himself commits a wrong. Wrongdoing in this sense is thus a necessary, if not a sufficient, condition for punishment. ${ }^{28}$

Any account of the criminal defenses will therefore have to invoke both utilitarian assumptions and intuitions of justice and retribution. If Fletcher is correct, an account of justification depends on using these resources to analyze the distinction between harm and wrong and to show that justified conduct is harmful and not wrong. Excused conduct, on his account, is both harmful and wrong, but nonetheless the results are not "attributable" to the actor and therefore punishment is not appropriate. To explain this, Fletcher distinguishes between willful or purposeful choice and attenuated or diminished self-control because of exigent circumstances. ${ }^{29}$ For hu-

27 Fletcher's discussion of retribution as the relevant ordering principle for the proper understanding of the structure of justifications and excuses is presented in Fletcher, supra note 1 , at 961 . A much fuller and significantly different analysis of the foundations of wrongdoing appears in G. FLETCHER, supra note 3, at 454-91, 552-69. See also supra note 7 . Although I argue that the concept of wrongdoing is both ambiguous and overdetermined, see infra text accompanying notes $45-55$, my provisional adoption of a roughly utilitarian account of wrongdoing does not reflect a disagreement with Fletcher's point that, in the final analysis, our sentiments about wrongdoing also roughly track our sentiments about justice and punishment. This conclusion, however, leads me to disagree with Fletcher's point that determinations of wrongdoing and attribution are separate tasks since I argue that both are rooted in our sentiments about what is just.

28 The notion that sentiments of justice and retribution are a threshold for punishing, but that some additional justification is required once the threshold conditions are mel, is explained in H. HART, supra note 25, chapter 9; T. MORAWETZ, supra note 24, at 219-21; and Morawetz, Retributivism and Justice, 16 ConN. L. REv. 803 (1984).

20) See Fletcher, supra note 1, at 961-62. Throughout Fletcher's discussion, the salient featurc of excuses is the attenuation of control through some disability. Robinson scems to understand excuses in exactly the same way:

Each of the excused defenses has the following internal structure: a disability causing an excusing condition. The disability is the abnormal condition of the actor at the time of the offense. We say, for example, that the actor is suffering from insanity, intoxication, subnormality, or immaturity. The disability is a real condition with a varicty of obscrvable manifestations apart from the conduct constituting the offense.

Robinson, supra note 1 , at 221 (emphasis in the original). If this is indeed the mark of an 
manitarian or compassionate reasons, ${ }^{30}$ certain kinds of wrongful behavior may be excused because the actor did not and could not be expected to exercise choice and control. The reasons may be internal or external: temporary derangement because of intoxication or illness, or external pressure from threats or coercion. Intoxication, insanity, and duress are recognized as excuses or as bases of diminished responsibility. ${ }^{31}$ Wrongdoing is present, but justice does not mandate punishment. ${ }^{32}$ Thus, Fletcher invokes justice and retribution as relevant to the second question, the question of attribution.

Two important consequences flow from explaining justification in terms of the absence of wrongdoing and explaining excuses in terms of the justice of attribution and punishment. Suppose that $\mathrm{Al}$ sees Bo struggling with Cal, wrongly imagines that Bo has assaulted Cal, and goes to Cal's aid. If Bo is in fact a policeman effecting an arrest or a victim resisting Cal's original attack, Al's misconceived intervention is excusable but not justifiable. Since Bo's action is not a wrong, forcible interference with it is a wrong, albeit an excusable one. On the other hand, if Bo is in fact the aggressor (whether excusable or not), Al's intervention is justifiable. ${ }^{33}$ (Just as Cal is privileged to defend himself, $\mathrm{Al}$ is privileged to go to his assistance.) In general, then, according to this model, ${ }^{34}$ interference with justifiable behavior can only be excused, not justified, while interference with excusable behavior can be justified.

The second consequence of distinguishing justifications from excuses in this way is that one separates judgments about acts from

excuse, then mistake and duress are surely not excusing conditions, as I argue in Parts I and III. An exigent circumstance is not the same thing as a disability; if it were, selfdefense would be an excuse. Throughout his article, Robinson is uncharacteristically vague in defining mistake, hampered as he is by a counterintuitive linkage between mistake and disability. Robinson, supra note 1, passim.

30 The terms are Fletcher's. See supra note 29.

31 Three points are significant: (1) Intoxication is an excuse only if it is "involuntary intoxication," i.e., if the actor was not reckless in becoming intoxicated, reckless in the sense of being able to anticipate in his misconduct. (2) In many cases of reckless conduct, intoxication may tend to mitigate rather than excuse the actor. (3) I discuss in part III infra whether duress is properly conceived of as an excuse. See also supra note 29.

32 Fletcher's reference to compassion raises the question of whether justice or mercy is the guiding moral principle behind excuses. See Fletcher, supra note 30. Can justice and mercy be distinguished in these situations?

33 As Robinson properly reminds us, the defensive responses that are properly classifiable as justifications include defense of others and defense of property, as well as selfdefense. See Robinson, supra note 1, at 215.

34 See Fletcher, supra note 1, at 964-71; Robinson, supra note 1, at 273, 278. Greenawalt's misgivings regarding the clarity of the distinction between justifications and excuses are, as I point out infra in Part IV, well grounded. See Greenawalt, supra note 1, at 1918-27. 
judgments about the blameworthiness of actors. In determining that an act is justified and therefore not wrong, one need not refer to idiosyncratic characteristics of the actor. In excusing a wrong, on the other hand, one must take into account these idiosyncratic characterstics. ${ }^{35}$ One finds, for example, exigent circumstances to show how and why self-control in the particular case was diminished or absent.

This analysis of justifications and excuses has the virtue of clarity, but faces the following problems. First, many familiar defenses do not fit comfortably into this framework. Not all cases of excusable wrongdoing are cases of diminished control or derangement of purpose. The most obvious example is reasonable mistake. ${ }^{36}$ For instance, if Dee puts white powder from the sugar bowl into Eldon's cocoa and has every reason to think that it is sugar, but in fact it is poison, Dee's defense is mistake of fact, ${ }^{37}$ as every first-year law student knows. But is this a justification or an excuse? Dee will say that her belief that the substance was sugar was justified since she had good reasons for thinking so and no reason to think otherwise. Because she had good reasons for believing what she did, she also had good reasons for acting as she did. She will say, correctly, that no one would have suspected that the "sugar" was poison.

Another example illustrates the same point. Flo, a police officer walking in a deserted alley sees looming before her the silhouette of an armed man. She turns and shoots the child with a toy gun who produced the looming shadow. Assume there is no negligence in her actions. She will claim mistake and say, again correctly, that she had good and sufficient reasons for her actions, and therefore that she was justified in doing what she did.

Cases of reasonable mistake and putative self-defense are usually counted as cases of excused misconduct. Unlike privileged acts

35 See supra note 18 .

36 See supra note 17. In chapter nine of Rethinking Griminal Law, Fletcher offers a compendious inventory of the various kinds of mistakes that can affect our perception of the actor's culpability. He goes on to discuss several theories about the relevance of mistakes to culpability. Obviously I cannot do justice to this analysis. I restrict my examples to mistakes of fact falling within the categories of mistakes about the elements of the definition and mistakes related to justificatory claims. Fletcher's list and examples appear in G. FLETCHER, supra note 3, at 684-85.

37 The use within criminal law of the term "mistake" seems to some extent to be at odds with ordinary usage. In criminal law we refer to a relevant false belief as a mistake whether or not there was any possibility of the actor arriving at a true belief instead of the false belief. In ordinary discourse we say that someone made a mistake only if it was possible for him not to have made a mistake. Thus, in law "mistake" does not necessarily carry the connotation of fault, while in ordinary discourse it does. I am indebted to Arthur Hessel for pointing this out to me. 
of law enforcement and acts of genuine self-defense these actions are not encouraged by society. They are to be seen as regrettable accidents; no one is made better off by them and a utilitarian would have no trouble condemning them (but not necessarily punishing them). ${ }^{38}$ At the same time they do not have the salient characteristic of excused conduct. ${ }^{39}$ The actor is in control, is acting purposefully and on the basis of good reasons. There is no suggestion of inner or outer coercion or derangement.

Ordinary linguistic usage seems to support the notion that this behavior is justified rather than excused. In this respect, Greenawalt seems correct when he argues that acting on good reasons is the essence of justified action. ${ }^{40}$ However, the structure of justified action on the basis of good reasons is distinguishable from the structure of such legal justifications as privilege and simple self-defense. In the former cases, the actor has good and sufficient reasons for action but they are incomplete reasons from the point of view of hindsight or omniscience. One must distinguish what the actor could have been expected to know and do from what the actor may come to know after the fact or what the omniscient observer would know. It is important that one does not say an actor is justified if he has any reasons whatever for acting; ${ }^{41}$ only good reasons in the senses required by law will do. This is captured by the requirement that the mistake be reasonable.

38 See supra note 24 . A utilitarian would not punish if the result would merely be the accumulation of harm with no offsetting benefits.

39 Here I am adopting Fletcher's and Robinson's account of the distinguishing marks of excuses. See supra note 29.

40 See Greenawalt, supra note 1 , at 1903.

"Justified" is most definitely not a special legal term. In discussions of ethics, justified action is morally proper action. "Justification" is also used in relation to the reasons one puts forward for one's choices; an action is "justified" in this sense when one has defended it with sound arguments. ... In epistemology, reference is made to "justified" belief, belief about facts that is well-founded. What joins these various senses is the idea that to be justified is to have sound, good reasons for what one does or believes.

See id. This seems to be quite correct, and it reflects the distinction made by philosophers (and based on observations of usage) between justified belief and true belief. A justified belief can be false; it is justified if there are good reasons for holding it. Fletcher seems to reject this analysis of justification throughout his article, but this is especially evident when he says that putative self-defense (grounded on a well-founded but erroneous belief that one is threatened) can be an excuse but not a justification. Sep Fletcher, supra note 1.

41 Throughout his discussion of putative self-defense Fletcher clearly regards it as irrelevant whether the actor had good reasons for acting as he did or whether he simply had reasons for doing so. Fletcher, supra note 1, at 973-77. Presumably he would regard the distinction as relevant to the question of the availability of excuse, but it is hard to see how that argument could be made, given the linkage between excuses and disabilities. 
It will be said that this extended account of justified conduct confuses the notion that the mistaken actor is justified with the claim that the actor thinks and believes erroneously that she is justified but is in fact, from the point of view of law, only excused. The diffculty with this objection is that the actor does not really "believe she is justified." What she believes is that the substance is sugar, and that Eldon wants sugar in his coffee, or that the shadow is of a dangerous assailant. The notions of justification and excuses are on the one hand, part of a meta-language or observer language used to describe their situation. From the standpoint of this meta-language it is appropriate to say that having good, albeit erroneous, reasons is the criterion for being justified. The person who is unreasonable in judgment, however, incorrectly believes that she has good reasons for acting. That person is unjustified. Clarity commends this account over one that says the actor who has good, if erroneous, reasons thinks she is justified but is not.

If it is appropriate to say that such mistaken behavior is nonetheless justified, it is necessary to distinguish these cases from such familiar cases of justification as privilege and self-defense. ${ }^{42}$ Fletcher distinguishes harms from wrongs and commends a roughly utilitarian criterion for wrongs. ${ }^{43}$ Privileged and self-defensive actions are immediately harmful, but not harmful on balance and therefore not wrong. Not only are the individual acts justified but so is the policy of encouraging persons to defend themselves and of training enforcement officers to use appropriate force to restrain dangerous offenders. Harm caused by justified mistake, on the other hand, is not the sort of harm that is bound inextricably to ultimate benefits. It is also not the vindication of personal rights and privileges. ${ }^{44}$ If these features mark what is wrong, then it seems appropriate to use the phrases "justified act tout court" for the first kind of act and "justified wrong" for the second. At the same time we can reserve the term "excused act" (or "excused wrong") for

42 Thus we need two discrete classes of justified conduct, pure and simple justified conduct and what I call justified wrongs.

43 See supra note 7.

44 In other words, if justifications like self-defense and privilege are morally overdetermined, accommodating both a utilitarian account and an account in terms of the vindication of rights, the same cannot be said about so-called justified wrongs. Or perhaps a utilitarian argument is available but more remote, if one can establish that recognizing the defense of mistake does have long term benefit. I suspect that the benefit involved would be in some respects inseparable from whatever benefits are derived from a general sense that persons are treated fairly or justly. If that is true, then utilitarian accounts and accounts in terms of justice and rights are not as easily separable as one might suppose. 
wrongs committed by persons who lack the ordinary resources of deliberation and control.

One caveat should be noted. The term "justified wrong" is potentially misleading. What is justified is the mistake and the action, but not the result. Dee is justified in thinking the white substance is sugar. She is not justified in killing Eldon. To say that she is justified in killing Eldon is to imply that she would be justified in killing him intentionally, and that is not true. Accordingly, neither the term "justification" nor the term "excuse" is fully satisfactory. Dee's mistake was justified and therefore we excuse the consequences.

\section{The Criteria of Wrongness and the Defense of Necessity}

The distinction and relationship between harms and wrongs deserve additional scrutiny. This can be done by reconsidering some of the limitations of a utilitarian account of the criminal defenses and then looking at other criteria for wrongness.

In the individual case of self-defense, the defender may in fact inflict more or as much harm on the attacker than the attacker originally intended or was likely to cause. The justifiability of the act does not depend on minimization of harm in the particular case. This does not mean, however, that standard cases of simple selfdefense cannot be rendered understandable by a utilitarian account. All the utilitarian needs to argue is that harmful behavior is likely to be minimized overall by a policy of encouraging self-defense than by a different policy. Legal recognition of self-defense may, for example, discourage attackers who know that their intended victims are thus legally permitted to inflict harm on their attacker.

This revised utilitarian analysis may be criticized by those who would argue that empirical consequences should be irrelevant. One has a right, it will be said, to defend oneself even if defenders as a rule inflict more harm than attackers and even if attackers are not deterred by the legal recognition of the right of self-defense. Such an argument may be grounded on the notion of a fundamental right of self-preservation, represented by a basic moral requirement of respect for the physical and mental integrity of persons regardless of the consequences. ${ }^{45}$ Accordingly, the recognition of self-defense

45 I am making no assumption about the kind of theory of rights that lies in the background. In particular I am not claiming that there are universal rights derivable from human nature or that rights are traceable to a hypothetical social contract. The first kind of theory has recently been worked out by Alan Gewirth and the second by John Rawis. See A. Gewirth, Human Rights (1982); J. Rawls, A Theory of Justice (1971). The notion that a fundamental right is the right to be treated equally with all persons and 
is morally overdetermined. Various theories of wrongness imply such recognition.

A more serious problem arises with what I have termed justified wrongs. A utilitarian may have trouble showing the moral basis of the defense of mistake of fact. The participants are clearly worse off as a result of the harmful and mistaken conduct than they would be if it had not occurred. If the utilitarian's concern, however, is with the consequences of punishing the conduct, he can argue in favor of exculpation on the grounds that harming the agent merely makes the situation worse. There may, however, be offsetting benefits from the punishment of justified wrongs. A policy of disallowing the defense of reasonable mistake may make persons more careful to investigate the grounds of their conduct. ${ }^{46}$ To say that Flo had good reasons for her mistake is compatible with saying that we may require extraordinary care when the lives of innocent persons may be lost. 47

The utilitarian has a harder time explaining the defense of mistake of fact than does the theorist who invokes justice and rights. It is a basic norm of criminal law that it is just to punish only those who have had an opportunity to shape their conduct to the demands of law, ${ }^{48}$ only those who have acted purposefully to cause the sorts of harms that the law forbids or those who have failed to take expected precautions and care. Singling out for punishment persons who have acted innocently and with good reasons seems to flout a basic norm of justice, a right not to be punished without fault.

The treatment of mistakes within Fletcher's framework is significant. They are instances of wrongdoing both by utilitarian criteria, since society seeks to minimize such conduct, and by criteria of

with respect and concern is elaborated by Ronald Dworkin. See R. Dworkin, Taking Rights Seriously (1977). There would seem to be two aspects to the recognition of such a right, a passive aspect (the right to expect others to respect one's integrity and autonomy) and an active aspect (the right to take action to see that one's autonomy and integrity are safeguarded).

46 To work out this argument in detail one would have to attend separately to the several kinds of mistake identified by Fletcher and work out the implications for each. See Fletcher, supra note 36 . In this particular example it is hard to see what duty of care could have been imposed on the person.

47 See supra note 3 , comment 2 . This point puts in question the relationship between law and morality insofar as each may affect the other over time. By making persons strictly liable for certain kinds of conduct, or at least by disallowing particular defenses and imposing a high standard of care with punishment for those who fall short, the law may change the way the act is conceived morally. For example, by imposing severe penalties on drunk drivers and by making liable as accomplices those who contribute to drunkenness, the law may change moral attitudes. Accordingly, morality cannot be seen as a fixed and immutable set of norms to which the law simply may or may not conform.

$48 \mathrm{See}$ H. HART, supra note 25, at 158-85. 
blame and retribution. Both criteria mark the boundaries of wrongdoing and thus the boundaries between justifications and excuses. Nonetheless, Fletcher concludes that even though a retributive response is appropriate in those cases, such acts are excused for humanitarian reasons because of the special situation of the actor.

Why does Fletcher say that most observers would seek retribution from actors like Dee and Flo? To be sure, observers and actors may regret such actions and actors may feel remorse, but feeling regret and remorse has little to do with retribution. (Regret over the outcome may even be appropriate in cases of pure self-defense.) It seems counterintuitive to argue first that certain acts are wrong and that retributive feelings are appropriate, and then to ask whether punishment is just and whether there are humanitarian reasons not to punish. This reasoning seems counterintutitive because judgments about wrongness and retribution are not independent from judgments about justice, but dependent on them. It is clear that it is just to exculpate Dee and Flo; it is much less clear that their conduct is "right" or how a relevant criterion for wrongness and rightness can be framed.

Fletcher's analysis is motivated in the following manner. First, the conclusion that acts of self-defense, etc., are not wrong is overdetermined.49 It can be supported by utilitarian reasons or by reasons having to do with rights and just treatment. At this point it is not necessary to decide whether a utilitarian calculus of harm and benefit or intuitions about justice form a sufficient criterion for wrongness. When one comes to explaining excuses, however, it is necessary to explain why it is unjust to punish. This seems to suggest, as Fletcher argues, that the question of wrongness is sufficiently determined by utilitarian considerations, leaving questions of attribution and punishment to be decided on the basis of justice.

This conclusion, however, poses a dilemma. On the one hand, a utilitarian criterion for wrongness is unsatisfactory because it makes the rightness or wrongness of self-defense depend on an empirical calculation of net benefit. It does not allow us to distinguish wrongs from (net) harms to conclude that only some harms are wrongs. ${ }^{50}$ On the other hand, in rejecting a utilitarian criterion for

49 See supra text accompanying note 45.

50 Throughout this article I ignore wrongful conduct that does not involve harm. Attempts to cause harm are of course the most obvious example of crimes that do not involve harm. Although each of the criminal defenses could also be raised against a charge of attempt, consideration of attempts would add nothing to my analysis. In his discussion of the relationship between wrongdoing and harm, Fletcher is correct that harm is not a necessary ingredient of wrongdoing, that acts intended to cause harm may 
wrongness one cannot go so far as to say that only purposeful or negligent harm-causing is wrong, because this account is too narrow. It excludes innocent mistakes from the domain of wrongdoing. There is a need for a middle position, and Fletcher seems to aspire to one when he suggests that wrongs are those (net) harmcausings that are appropriately accompanied by a retributive feeling or demand. 51

Such use of the notion of retribution produces an unstable theory. First, it appeals to intuitions about retribution that are uncertain. Does one really seek retribution from those who innocently and mistakenly cause harm? Secondly, it severs intuitions about retribution from intuitions about just treatment even though, conceptually, the sense of retribution seems to depend on the sense of justice as its clearest component. 52

The implications of this analysis is that the notions of wrongdoing and retribution hover in a no-man's-land of concepts between two relatively clear notions, harm and justice. However problematic the details, ${ }^{53}$ the utilitarian notion of a net general effect of greater benefit or greater harm is a determinable feature of many situations. Similarly, it is often clear what justice demands in regard to persons who harm even when the explanations of such intuitions vary and are disputable. 54 By comparison, the use of the term "wrong"

be punishable whether or not they succeed. Rethinking Criminal. Law, supra note 3, at 472-83. In The Right and the Reasonable, Fletcher restricts his analysis to acts that have succeeded. See Fletcher, supra note 1 . I restrict my discussion here in the same way.

51 Fletcher discusses the motivations for treating $W$ (wrongdoing) as preceding $R$ (determinations of responsibility) in The Right and the Reasonable. See Fletcher, supra note 1 , at 958-60.

52 See Morawetz, Retributivism and Justice, supra note 28, at 815-20. Among other things I suggest that the clearest relevant intuition of justice is that blameworthiness or desert is a necessary condition or a threshold for punishing. The retributivist would seem to hold that it is also a sufficient condition for punishing as well and that it is mandated by justice. Following Hart, I question this conclusion. See also H. HarT, supra note 25.

53 It is always easier to produce the data to be explained than to produce the explanation. Over a wide range of situations we know when the individual, another person, or society as a whole is better or worse off. We draw on knowledge of human satisfactions, desires, and needs; we are prepared to defend our conclusions and insights. But it is harder to explain and justify our knowledge of human nature, of benefit and harm, as well as our knowledge that some conclusions are seriously debatable and others are not. Attempts by utilitarians to identify the ingredients of judgments about benefit and harm have produced both disagreement over the particular analysis and skepticism over the possibility of giving any such analysis.

54 See supra note 53. Attempts to formulate the principles of justice have met the same fate as attempts to clarify benefit, harm, and utility. In Retributivism and Justice and other forthcoming work, I suggest that some questions may be answered by noticing that intuitions about benefit and justice may be more closely related to each other than is generally assumed. See Morawetz, supra note 28. 
seems unsettled, sometimes colored by utilitarian criteria and sometimes by considerations of justice.

The phrase "justified wrong" is useful in severing the criteria for justification from the criteria for a wrong. It is somewhat defective, however, in failing to capture the unsettled character of the notion of wrongful conduct. Regarding mistaken harm-causing as a kind of "justified wrong"55 presupposes the utilitarian criterion that an act is wrong insofar as persons would be better off if acts of that kind did not occur. By this criterion privilege and pure self-defense are not instances of wrongs, while harmful mistakes are wrongs. The criterion for just punishment, involving as it does the fair opportunity to comply with the law, is a different moral standard and is not satisfied when those who make reasonable mistakes are punished.

Confusion over the criteria for wrongness affects the analysis of the defense of necessity or lesser evils. To plead necessity is to concede that one has caused a harm in violation of the letter of the law and to argue that one has done so only to avoid the alternative of bringing about an even greater harm. For example, one may be able to stop a forest fire only by trespassing and destroying private property by creating a firebreak, and he whose family is starving may be able to save them only by stealing food. Like privilege and selfdefense, acts under the color of necessity involve deliberate choice and seem classifiable as justified acts tout court. They arguably involve socially approved conduct, conduct that may reasonably be encouraged.

Some commentators argue that necessity identifies the overarching concept of legal justification and includes privilege and selfdefense as subcategories. ${ }^{56}$ Assaulting one's attacker is said to be the lesser evil when compared with acquiescence. There are two problems with this argument. One is that self-defense applies even in situations in which harm to the attacker may be as great as the harm threatened. The second is that necessity is often applied when the actor must choose between two affirmative actions (as in the first example) while self-defense characteristically refers to the choice between action and acquiescence. ${ }^{57}$

Uncertainties about the necessity defense persist and they re-

55 See supra text accompanying note 42.

56 See Robinson, supra note 3, at 213-14; Morawetz, Justification: Necessity, in EnCYCLoPEDIA OF CRIME AND Justice 959.

57 This is only roughly true. In many necessity situations the actor must choose between letting a seriously harmful action happen (the forest fire sweeping across the landscape) and intervening to prevent it by bringing about evil (taking property to create a 
flect uncertainty about the criteria of wrongness. Justification in the case of privilege and self-defense is morally overdetermined, supported and explained both by utilitarian theories and theories of justice. Is this so with necessity? Utilitarian theories again seem to be relevant. The necessity defense is an endorsement of the principle of minimizing harm in the particular case and, a fortiori, minimizing harm in general. Justice, however, is more problematic. The privileged acts of the police and the defensive acts of the would-be victim are justified at least in part because the person harmed has been an aggressor, has forfeited in part ${ }^{58}$ her putative right to be respected and free of harm. The same cannot be said of the innocent victims of the necessary action. The man whose property is destroyed for a firebreak or the family swept away by the flood diverted from a town center to a park would seem to have the same rights as anyone else. Moral intuitions are most uncertain when we are required to count lives. Is it justifiable to kill one merely to save two ${ }^{59}$ And is it justifiable to kill one when it is merely probable that many others would otherwise die? ${ }^{60}$ It seems obvious that a doctor would not be justified in sacrificing one healthy patient in order to transplant eight body parts into eight patients who would otherwise surely die, even if the would-be donor is uniquely compatible with the would-be recipients. The same doctor, it seems, could justifiably kill one person by steering his runaway car toward him if the only alternative were to drive into a crowd of eight pedestrians.

There seems to be no clear answer to this dilemma. It shows both that utilitarian intuitions have a major role in determining wrongness and that they tell us less than the whole moral story. If the doctor's actions in the first situation are clearly wrong, then wrongness has little to do with counting lives and much to do with

firebreak). Nonetheless, the context of the necessity defense is characteristically described as one in which the actor may choose a greater or lesser evil.

58 The aggressor has only forfeited these rights in part. The justification of self-defense extends only to a proportional response. The person who responds disproportionately, for example by killing an escaping felon who does not threaten violence or a thief who does not place the victim's person at risk, does not have a complete defense. See Robinson, supra note 1, at 216.

59 Our reliance on a consensus of intuition breaks down when lives are at stake. We have conflicting intuitions: that each life is of infinite value, that some lives are more valuable than others, that it is better to save more lives than fewer. We seem to be clear that taking lives is worse than taking property and we tend to have clear intuitions about situations in which we have to compare lesser harms. But only under cover of exigency do we permit persons to choose more lives over fewer and under that cover we may also put at grave risk many rescuers to save a single coal miner.

60 Some writers have thought that the distinction between killing and letting die is relevant, that taking a life is worse than allowing the taking of a life to happen. See, e.g., J. Finnis, Natural Law and Natural Rights 100-33 (1980). 
the rights of persons to safeguard their vital interests even when others may suffer. It is practicable for the would-be victim in the first case to call on the state to safeguard these interests, while it is not practicable to do so in the exigent second situation. This difference is in some way related to the fact that we can set rules for the protection of would-be victims in the first situation and can do nothing but leave matters to the actor in the second. The moral relevance of all this remains opaque, however. A theory that seeks to explain justification in terms of wrongdoing must in turn elucidate wrongdoing in terms of the underlying moral criteria of wrong and neither utilitarian criteria nor intuitions of justice are clear enough to be helpful. 61

\section{UnDERSTANDING DURESS}

In the tripartite framework of justified harms (justified acts tout court), justified wrongs, and excused conduct (involving diminution or lack of control), the criminal defense of duress presents special difficulties of classification. Consider, for example, the case of Gerd who, held at gunpoint, is forced to use her technical skill to rewire a car so that it will explode when the ignition is turned. Like the person who is acting in self-defense, she is choosing to act to avert harm to herself. Like the person who acts from mistake, she is acting on the basis of good reasons and yet is acting in a manner that society does not encourage or approve. Like the person who is intoxicated or deranged, she may perhaps be said to lack the normal resources of control over her actions. The act committed under duress, therefore, seems in some respects like a justified act, in others like a justified wrong, and in still others like an excusable act.

Each of these analogies is problematic. Taking the last first, one finds conceptual difficulty in treating duress as an excuse. The guiding hypothesis here is that the threat of immediate harm (to oneself or to others) ${ }^{62}$ takes away one's ordinary power and responsibility to control what one does. External coercion is analogized to

61 The inquiry must be carried out on a metaethical level, with such questions as whether utilitarian (or consequentialist) analysis is the sort of analysis that will explain wrongness, whether an act can be wrong and justified, whether justifications are related to just dispositions of cases, whether there is a useful distinction between committing a wrong and simply acting wrongly, and whether there is an equally important distinction between calling an act or outcome wrong and saying that the actor acted wrongly. It seems to me unhelpful to dismiss the relevance of moral philosophy on the ground that persons have different moral convictions and that some persons are likely to be a good deal more idealistic than others. See Greenawalt, supra note 1, at 1904-07, 1927.

62 Historically the defense of duress has been restricted in some periods and jurisdictions to threats to the actor and usually to threats to the actor or her family. The as- 
inner derangement. One typical standard for duress is that the actor will be excused if she acted in response to pressures that a person with normal capacities of self-control could not be expected to withstand. ${ }^{63}$ The idea is of a "will overborne." Acting under duress seems to be midway between controlling actions and being the unconscious agent of others (as if hypnotized). ${ }^{64}$

One difficulty with this account is that it presupposes a clearer theory of control and of the will than we really have. The actor under duress is surely aware of her choices and is choosing as deliberately as the person who acts under the pressures of self-defense and necessity. All are exigent situations. Yet in the case of such justifications as self-defense and necessity we do not claim to find an overborne will. These are situations of choice and control. These defenses are circumscribed by factors the actor is expected to take into account: self-defense is limited by the retreat restriction, ${ }^{65}$ and necessity is limited by the requirement that the actor must choose the lesser evil.66 The assumptions made about will, choice, and control in self-defense and necessity on the one hand and duress on the other seem inconsistent.

There are two options, to treat duress as an excuse but jettison the apparently arbitrary criterion for excuses, namely derangement causing lack of control, or to classify duress differently. Is duress a justified wrong? The mark of a justified wrong is that the actor has good reasons for acting, but at the same time takes actions that society (for utilitarian reasons) is anxious to discourage. ${ }^{67}$ Persons acting under mistaken beliefs have good reasons and are morally

sumption has been that only these sorts of threats would be likely to coerce a person of reasonable resilience.

63 See Model Penal Code, § 2.09 (Proposed Official Draft 1962).

64 The conventional legal analysis of the situation of hypnosis is that one has not really acted at all. This situation is analogized to any other kind of automatism or reflex behavior. Thus duress seems to represent partial control, half-way between full control and no control. I suggest in the text that this is conceptually crude and inadequate. By Robinson's categorization, the situation of hypnosis would represent not a justification or excuse, but a failure to satisfy the elements of the offense. See Robinson, supra note 1 .

65 Even if threatened by deadly force, one may not respond with deadly force if (a) one can retreat in perfect safety, (b) one knows one can do so, and (c) one is not in one's own home. See, e.g., Model Penal Code, § 3.04 (1)(b)(ii).

66 A general way of expressing my disagreement with Fletcher is with regard to whether choosing the true lesser evil and choosing the apparent lesser evil are to be treated the same way and are to be regarded equally as justified conduct. By my analysis, they would both be justified because in both cases they would involve actions backed by good reasons. Fletcher would regard guessing incorrectly (in the case of an apparent lesser evil) as crucial, and the actor who guesses incorrectly could be excused but never justified. See Fletcher, supra note 1, at 971-77.

67 See supra text accompanying note 42. 
innocent. But can the same be said about those who act under duress?

In answering this question, one may get sidetracked by confusing good reasons for acting with moral reasons. Law does not require that people be particularly altruistic. The person who acts under an immediate and credible threat to himself is acting to avert that threat even at the cost of greater harm to other persons. Is this a good reason insofar as it warrants the claim that the actor was justified in acting as he did? The situation in a case of duress is radically different from that of mistake, in which the claim is genuinely one of moral innocence ("I had no reason to think that others would be harmed"). These reasons must be good reasons in quite a different sense from those that establish innocence, but they seem to be good reasons all the same.

It is clear that in nonexigent situations a preference for one's own interests and welfare becomes at some point monstrous and ceases to be a good reason. The sadistic killer for pleasure or the contract killer for money cannot claim to be justified by good reasons, because they appeal to a theory of personality and a scale of values that is generally rejected. It is important, nonetheless, to see that the claim of the person acting under duress is not altogether different. He too favors his own interest. A distinction between the cases is that the person acting under duress is seriously and imminently threatened, while the contract killer is not. What must be explained is why this difference means that the sadist or contract killer has no defense and the person acting under duress does. What are the moral as well as the legal limits of self-favoring? Understanding the criminal defense of duress depends not so much on understanding the will (and when it is overborne) as on understanding the morality of favoring the self. ${ }^{68}$

It can be argued, therefore, that harmful acts that are committed under duress could be called justified wrongs. They are neither excused acts, if the criterion for excusability is lack of control, nor justified acts, if the criterion for justifications is that society approves of such conduct (roughly for utilitarian reasons). Nonetheless, they are altogether different from mistakes, the other example of socalled "justified wrongs," in the conceptual problems they raise. In duress situations, one cannot say that the actor was justified in believing what he believed and therefore that the consequences of his ac-

68 See, e.g., Williams, Persons, Character and Morality, in Moral Luck (1981); Williams, Moral Luck, in MORAL LucK; Williams, Utilitarianism and Moral Self-Indulgence, in MORAL Luck; Williams, Internal and External Reasons, in Moral LuCK. 
tions are excused. 69 If it is justifiable to act defensively when one reponds to threats, then the consequences must be justified as well. Duress, self-defense, and law enforcement, all of which involve responses to exigent situations, all present cognate problems of determining when the response to threats and danger is appropriate and defensible, when it is understandable if regrettable, and when it is beyond justification and toleration.

\section{Third Parties: Rights and Responsibilities}

The concept of justified wrongs has implications for understanding the rights to act of third parties who interfere with justified or excused conduct. According to the widespread interpretation of these rights, ${ }^{70}$ those who interfere with justified behavior may offer excuses but not justifications in defense of their behavior, while those who interfere with excusable behavior may be justified in their actions. If justified behavior is approved because it is right and contributes to the welfare of persons overall, then interference with such behavior (interference with the police, restraining those who act in self-defense) is not to be encouraged, merely excused. On the other hand, if persons act in harmful ways out of ignorance or because they are not in control, it is justifiable and socially desirable to prevent them from doing so. ${ }^{71}$

This account gives rise to certain anomalies. If $\mathrm{Hal}$ sees Ida struggling with Jo and goes to Ida's aid, the legal disposition of Hal's conduct will depend on whether he guesses correctly or not that Ida is being assaulted. If Jo, an undercover officer, is trying to arrest Ida and Hal interferes, Hal's conduct may or may not be excusable; the jurisdiction may or may not recognize the defense of mistake in such situations. ${ }^{72}$ If, on the other hand, he guesses correctly that Jo is an assailant, he has a complete justification. Since

69 See supra text accompanying notes $42-44$.

70 See Fletcher, supra note 1, at 971-77; Greenawalt, supra note 1, at 1918-27; Robinson, supra note 1, at 278-85. The litigation in People v. Young is instructive on this issue. 12 A.D.2d 262, 210 N.Y.S.2d 358 (1st Dept. 1961), rev'd, 11 N.Y.2d 274, 183 N.E.2d 319 (1962). The New York legislature's response is also instructive on this point. N.Y. PENAL LAW § 35.15 (McKinney 1975 \& Supp. 1987).

71 As I suggest infra at part III, it is difficult to accomodate these defenses (ignorance and mistake) within the confines of the standard conception of excuses as being defined by lack or diminution of control. Here I am bowing provisionally to the notion (which I reject elsewhere) that mistake is an excuse.

72 Many jurisdictions implement a policy of discouraging the intervention of volunteers during arrests made by undercover police officers by disallowing the defense of excuse and thereby placing the helper at risk if he guesses incorrectly about an apparent assault. See S. Kadish, S. Schulhofer \& M. Paulsen, Criminal Law and Its Processes $732-37$ (1983). 
some jurisdictions limit the availability of excuses but not of justifications in such cases, persons like $\mathrm{Hal}$ may bear a special risk when they choose to help. Arguably this is unjust. ${ }^{73}$

The analysis of justified wrongs eliminates such anomalies by implying that $\mathrm{Hal}$ is justified in either case. If Jo is simply enforcing the law, Hal has good reasons for intervening and, by committing harm, he carries out a justified wrong. If Jo is an assailant, $\mathrm{Hal}$ is justified as well. More generally, this analysis explains how someone who interferes with justified conduct can in turn be justified. Given discrepancies in reasonably available information and in the interpretation of contexts, the first person can have good reasons for acting in a way that is prima facie harmful and the second can have good reasons for trying to stop her. ${ }^{74}$ Any problem of interpretation lies not with the idea that "justification" is being used in paradoxical or contradictory ways, but with the notion of good reasons. At what point does negligence, willful ignorance, or unreasonableness vitiate the claim of an actor that he acted on good reasons?

\section{Judging Acts And Judging Actors}

It is misleading to argue with Fletcher that justifications refer to generic characteristics of a situation, for example to whether it involves wrongdoing, and that excuses are determined by such personal characteristics of actors as lack of control. The distinction is sometimes described as a distinction between objective and subjective features, wrongdoing being objective and lack of control being

73 See supra note 72 . In these situations, the actor, if he guesses correctly, has a justification. Conversely, if the actor guesses incorrectly, he may be prosecuted on several possible grounds. The questionable basis for this policy is that erroneous interventions are more costly to society and are not outweighed by the benefits of voluntary assistance.

74 By this method one can straightforwardly account for the counter-examples that Greenawalt offers to Fletcher. The case of People v. Young, 11 N.Y.2d 274, 183 N.E.2d 319 (1962)(reversing 12 App. Div. 2d 262, 210 N.Y.S.2d 358 (1961)), involves an intervention by a volunteer in a situation of plainclothes officers trying to make an arrest for disorderly conduct. The New York Court of Appeals held that one who goes to the aid of a third person "does so at his own peril," that he has no effective defense of honest mistake against a charge in this situation. Id. at 275,183 N.E.2d at 319 . The New York legislature finally codified such a defense in N.Y. Penal Law § 35.15. See Greenawalt, supra note 1, at 1919-21. Similarly, Greenawalt's counterexamples, see Greenawalt, supra note 1, at 1922, 1924, are effectively explained by the "good reasons" criterion for justifications. For example, Greenawalt conjures up two weak combatants, John and Mike, of which John is the attacker and Mike acts in self-defense, both with deadly weapons. Greenawalt says correctly that a strong third person (Arnold) who can keep each from harming the other would be justified in intervening. Arnold would thus have a justification for preventing a justified act (Mike's self-defense). If the "good reasons" approach is correct such examples should be easily anticipatable. 
subjective. ${ }^{75}$

Both parts of the distinction are puzzling. What does it mean to say that wrongdoing is objective? If wrongdoing were the same as harmdoing, it could be argued that harmdoing has objective criteria. The two, however, cannot be identified. ${ }^{76}$ If wrongdoing, on the other hand, is identified with unjustified harmdoing then the objectivity of the notion depends on the objectivity of the criteria for justification. These criteria, in turn, make reference to the motives and attitudes of the actor as well as to what the actor succeeded in doing. The necessity defense, for example, depends essentially on whether the actor reasonably believed that she had chosen the lesser evil. Self-defense is not available to every person who assaults a potential attacker but only to those who are aware of the attacker's intentions. The person who harms another not knowing or guessing that her victim would in turn have attacked her cannot plead self-defense when the victim's intentions are learned after the fact. Thus, the availability of justification defenses seems to depend on so-called subjective factors.

The suggestion that the determination of an excuse involves an essentially subjective assessment of the condition of the offender is also easily questioned. The dubious hypothesis about excuses is that they depend on abnormal subjective conditions and experiences. In fact, however, both excusable and inexcusable conduct have subjective dimensions and it is idle to suggest that one or the other situation is normal. The determination of the absence or the presence of excusing conditions and the determination of the presence or absence of justification are all "subjective" investigations. The main difference is that the subjective investigations relevant to justifications involve conditions pertaining to belief and the determinants of judgment, while investigations relevant to excuses involve the prevention or derangement of the process of judgment. ${ }^{77}$

75 See quotations, supra note 18. By "objective" I mean "determinable without reference to the state of mind of the actor" and by "subjective" I mean "determinable only by reference to the state of mind of the actor." This distinction differs from the usage of those who mean by an "objective" standard that, once the actor's state of mind has been ascertained, his conduct should then be measured against what the normal reasonable person would have done.

76 See supra text accompanying notes $42-45$.

77 Cf. Greenawalt, supra note 1 , at 1903.

"Justification" is ... used in relation to the reasons one puts forward for one's choices; an action is "justified" in this sense when one has defended it with sound arguments .... In epistimology, reference is made to "justified" belief about facts that is well-founded. What joins these various senses is the idea that to be justified is to have sound, good reasons for what one does or believes.

Greenawalt, supra note 1 , at 1903. An excuse, on the other hand, involves, according to 
A similarly defective characterization of justifications and excuses says that judgments about justifications are made at a higher level of generalization from judgments about excusable behavior. Thus, the statement that all law enforcement officers are justified in using necessary force to arrest or restrain dangerous offenders identifies a kind of justification by locating a general principle. Statements about excusable behavior, on the other hand, are said to pick out idiosyncratic, personal characteristics of the actor and are not generalizable. ${ }^{78}$

This distinction is hardly convincing. Why is the statement that Ida is involuntarily intoxicated any more idiosyncratic and personal than the statement that Jo is a police officer or that Kay believes that stealing food is necessary? In each case something said about Ida, Jo, or Kay distinguishes her from most persons and puts her in a limited class; in each case the statement substantiates a more general norm. The characteristic picked out for Ida (as the basis of an excuse) and for Kay (as the basis for justification) seems relatively situation-specific, bounded in time, but even this distinction is misleading. Ida's intoxication may extend over a series of situations as may Jo's perhaps temporary ${ }^{79}$ status as a police officer. Certainly no clear rule emerges for distinguishing the personal characteristics or degree of generality relevant only to excuses and not to justifications.

\section{On Structured Analysis and Its Uses}

What is to be gained by clarifying the distinction between justifications and excuses? Three questions must be distinguished.

(1) Given (a) that there is a distinction in moral usage between the concepts of justification and excuse, (b) that this distinction is

Robinson, "a disability causing an excusing condition. We say for example, that the actor is suffering from insanity, intoxication, subnormality, or immaturity." Robinson, supra note 1, at 211 . Robinson goes on to say that there are two kinds of disabilities: long-term and short-term.

78 Cf. Greenawalt, supra note 1, 1915.

What does it mean to say that excuses are individual and justifications general? Roughly, the idea is that an excuse does not reach others who perform similar acts, but a valid justification would apply to anyone else in similar conditions. Exactly what this contrast amounts to is somewhat cloudy. In the broadest sense of "universalizability," common to discussions of moral philosophy, excuses as well as justifications are general: all persons with similar mental disturbances committing similar acts would have a similar excuse based on mental illness. The point must be that excuses, but not justifications, are based on personal characteristics or subjective attributes.

Greenawalt, supra note 1, at 1915.

79 For example, one may be temporarily deputized for a particular occasion. 
borrowed by the common law from ordinary language, and (c) that the so-called criminal defenses tend to be classified as justifications or excuses, what is the distinction? What coherence, incoherence, and sticking points are there in the categories as generally used?

(2) Can the answers to question (1) be used to turn hard cases into easy ones? Does the analysis of justification and excuses yield a single hard-edged distinction that allows one to classify with ease and without ambiguity those cases and situations which may otherwise seem problematic? Or does the anlaysis simply leave things better illuminated by showing why problematic cases are problematic?80

(3) Can this analysis be used for practical reform? Should legislators rewrite criminal codes using a reformed and clearer distinction? Should juries be instructed to give special verdicts stating whether they have found excuses or justifications relevant and decisive? Ought judges at least to instruct juries to think about the differences between excuses and justifications and distinguish clearly between them?81

This article addresses primarily the first question. The notion of justification is ambiguous, standing both for interventions that society wishes to encourage because they have socially desirable consequences and for acts done for good reasons. The second class can be said to encompass the first. By adopting the second conception, one can account for two kinds of justified behavior, behavior done for what are good reasons without regard to perspective (or from the perspective of society at large) and behavior done for what seem to be good reasons from the perspective of the actor. ${ }^{82}$ The latter subcategory allows one to account (in very different ways) for mistake and duress, and for limitations on the defense of necessity. ${ }^{83}$ It is important to see that requiring the actor to have good reasons from his perspective is not the same thing as requiring the actor to have reasons tout court. Accordingly, a mistake must be reasonable and the action that follows from it must be a reasonable response to the reasonably misunderstood situation. This is moral

80 See L. WrTtGenstein, supra note 21 , part I, \$ 124.

81 Greenawalt, supra note 1 , at $1900-02$, is also concerned with the relation of theoretical and practical questions.

82 This is likely to be misunderstood. As the text makes clear below, "good reasons from the perspective of the actor" does not refer to whatever the actor thinks are good reasons, but rather, to what are good reasons from the standpoint of society's modes of evaluating and are reasons guiding the actor.

83 Mistake, necessity, and duress are discussed respectively supra in parts I, II, and III. The various limitations on the necessity defense are discussed in my article Justification: Necessity, supra note 56, at 958. 
as well as cognitive reasonableness. The act of the person under duress must reflect a morally acceptable preference of self over others, or of some persons over others. I have adopted, with some trepidation, ${ }^{84}$ the notion that excuses are best identified with diminished control through incapacity and with negligence. ${ }^{85}$

With respect to the second set of questions, this analysis explains why hard cases are hard, not how they can be made easy. The notions of a reasonable mistake and of a reasonable moral preference for self are notions about which people's opinions will continue to differ. Disagreement persists not only between persons with high moral standards and persons with lenient ones.86 The point, for example, at which a medical mistake becomes negligent, the ways in which a reasonable mistake by a medical intern differs from what is reasonable in the performance of an experienced physician, must in the final analysis be decided case by case. Something, but not much, can be decided by anticipatory general rules. The same can be said about duress. The ways in which exigency and fear complicate human choice and compel leniency in deciding whether an actor had good reasons for yielding to threats are inevitably controversial.

The third set of questions is quite separate, ${ }^{87}$ and encompasses a range of additional issues. One would have to know more than we do about the psychology of juries to know whether they would be helped or confused by analytical instructions on the justification/excuse distinction. This is a separate issue from the merits of the general verdict. As others have argued persuasively, there are good reasons for its retention. ${ }^{88}$ Those reasons are not so much that persons have different moral convictions as that they have different conceptions of limits and endurance, of man's capacities for circumspection and deliberation, and so forth. ${ }^{89}$ Defenders of the general verdict argue persuasively that agreement on guilt and exculpation can be reached without agreement about these conceptual

84 The notion of self-control and the limits of personal responsibility are explained in many ways and are the subjects of much disagreement. See S. Hampshire, FreEdom of the Individual (1975); J. TRusted, Free Will and Responsibility (1984).

85 See supra parts I and III.

86 Greenawalt appears to think that the main relevant difference is between those who do and those who do not hold a perfectionist ethical code, those who stress what is mandatory and those who stress what is permissable. See Greenawalt, supra note 1, at 1904-05.

87 See supra note 81 .

88 The merits of general and specific verdicts are discussed by Rohinson in Robinson, supra note 1, at 246-47, 290, and by Greenawalt, supra note 1, at 1900-01.

89 These uncertainties go to the heart of the distinction between justification and cxcuses. See supra part III. 
boundaries. Additional issues are raised by such questions as whether criminal codes should reflect these categorical and conceptual distinctions, and whether judges' opinions should do so as well. These issues would take us beyond the scope of this article into the role of texts in legal interpretation.

Is a response only to the first set of questions worthless because it leaves legal practice unreformed? ${ }^{90}$ A critic misunderstands philosophy and its applications if he looks for a quick fix. ${ }^{91}$ An analysis responding to the first question does not leave everything untouched. The activity of thinking through the categories and their implications may purge inconsistency and nonsense from the discussion of these issues. Moreover, the goal of clarification is ambiguous. One can clarify concepts by describing their uses and showing how they are dependent on further concepts like that of "good reasons" or one can clarify by recommending different use with harder edges, rendering the concepts independent of such notions as "good reasons." 92 It is easy to get impatient with the first kind of clarification, with what J. L. Austin has called "linguistic phenomenology,"93 and to condemn clarification because the second kind cannot be accomplished. The first is, however, a genuine alternative to capitulation in the face of the slogan that terms have "fuzzy edges."

The notion of good reasons for action helps one characterize a category of defenses one may call "justified wrongs." This in turn is a useful analytic tool for sorting criminal defenses, in particular the defenses of mistake, duress, and necessity. This analysis is relevant as well to puzzling questions about third-party interventions, for example how one actor can be justified in acting and another can be justified in interfering with that action.

Methodologically this article describes and takes a middle ground between positions taken by Greenawalt and Fletcher in their recent work on criminal defenses. Greenawalt questions whether conceptual analysis of justifications and excuses will yield any clarifi-

90 Both Greenawalt and Fletcher seem to discuss the role of the investigation in relation to the possibility of reform.

91 See T. Morawetz, WitTGenstein and KNowledge, ch. vii (1978). Wittgenstein argues that philosophy "leaves everything as it is." L. WITTGEnSTEIN, supra note 21, at Part I $\$ 124$.

92 Greenawalt seems to confuse the two senses of clarification when he says that "[a]ny definition of legal justification that is more specific than an open-ended reference to morally relevant factors is virtually certain to treat as justified some instances in which special factors would make the act only excused, at best, from a moral point of view." Greenawalt, supra note 1, at 1914-15.

93 Austin, A Plea for Excuses, Philosophical Papers 130 (1961). 
cation of difficult cases, whose difficulty he attributes to the fuzziness of the concepts and to the diversity of moral beliefs. ${ }^{94}$ Fletcher, on the other hand, is Greenawalt's perfect foil because he seems to argue that both kinds of clarification can be accomplished at once, that structured thinking about these matters yields hardedged categories and answers to hard questions.

The distinction between flat and structured thinking may be a chimera. ${ }^{95}$ On the one hand, Fletcher's insistence that a determination about wrongdoing must precede a determination of blameworthiness for wrongdoing has the marks of a truism. At the same time, the notion that these are completely separable determinations is eroded by close analysis. The questions are easily separated when the wrong is palpable and the actor pleads some personal disability to control his conduct. The example of mistake, on the other hand, shows that there are multiple criteria for wrongness, and that they are inconclusive when the actor had good, morally defensible reasons but the result is one that society cannot approve. The criteria for wrongdoing and the criteria for the attribution of blame are neither identical nor wholly independent. We are comfortable separating the two notions when several alternative criteria of wrongdoing are satisfied, that is, when the classification is overdetermined. ${ }^{96}$ That is not the case with mistake.

Does a concession that the two questions are not always independent and that more categories than two (justification tout court, excuse tout court) are needed make one a "flat" thinker?97 No. One need not conclude that the punishability of actors and the admissibility of defenses is to be decided on an ad hoc, case by case basis, with appeal made only to the "reasonableness" of the conduct.98 Instead, one may use the categories analyzed above and have conceptual reasons for using those categories. In part those categories are marked off by the presence and absence of good reasons for action and due care and thus they inevitably make reference to whatever standard of conduct society condones. In that sense, the reasonableness of conduct must always be at issue and the relevant standard is always in part "objective." The criminal defenses as a

94 See supra note 74.

95 See supra introduction and part I. The analysis I give seems to have the same density as that which Fletcher calls "structured" thinking, but it lacks the sharp edges. As I indicate in the text, one can use the criterion of "reasonableness" without succumbing to "flat" thinking, Fletcher to the contrary notwithstanding.

96 See supra text accompanying notes 24-28 and 44-48.

97 Fletcher, supra note 1 , at 962-64.

98 Id. 
general matter are about what one can and cannot reasonably expect persons to do and what standards one can expect them to understand and act upon. This will inevitably engender hard questions that vitiate any attempt to anticipate judgments with hardedged concepts and to expunge "reasonableness" and its surrogates. 